\title{
Prevalence of Work-Related Asthma in Primary Health Care: Study Rationale and Design
}

\author{
Ventura Rabell-Santacana, ${ }^{*}$, Rafael Panadès-Valls ${ }^{2}$, Rosa Vila-Rigat ${ }^{3}$, \\ Enric Hernandez-Huet ${ }^{4}$, Joan Sivecas-Maristany ${ }^{5}$, Xavier Blanché-Prat ${ }^{6}$, \\ Gemma Prieto ${ }^{7}$ Laura Muñoz ${ }^{8}$, Pere Torán ${ }^{8}$ and Respiratory Research \\ Group of Vallès Oriental (GRRVO)
}

\begin{abstract}
${ }^{1}$ Primary Healthcare Centre Vallès Oriental, Catalan Health Institute, Carrer del Museu, 19, 08401 Granollers, Spain; ${ }^{2}$ Health and Safety Occupational Centre, Department of Business and Occupation, Plaça Eusebi Güell 4-5, 08034 Barcelona, Spain; ${ }^{3}$ Primary Healthcare Centre La Garriga, Catalan Health Institute, Carrer Torrent de la Sínia 7 , 08530 La Garriga, Spain; ${ }^{4}$ Primary Healthcare Centre Les Franqueses del Vallès, Catalan Health Institute, Carrer de Girona 290, 08520 Les Franqueses del Vallès, Spain; ${ }^{5}$ Primary Healthcare Centre Can Borràs, Catalan Health Institute Carrer, Balmes 51, 08440 Cardedeu, Spain; ${ }^{6}$ Primary Healthcare Centre Llinars del Vallès, Catalan Health Institute Carrer, Frederic Marès, s/n. 08450 Llinars del Vallès; ${ }^{7}$ Primary Care Management of Health of Ávila, Castilla y León (SACYL), Avenida de Portugal 47, 05001 Avila, Spain; ${ }^{8}$ Primary Healthcare Research Support Unit Metropolitana Nord.IDIAP Jordi Gol, Carrer Major 49-53, 08921 Santa Coloma de Gramenet, Spain
\end{abstract}

\begin{abstract}
Background: Occupational Asthma (OA) is the most frequent origin of occupational respiratory diseases in industrialized countries and accounts for between $5 \%$ and $25 \%$ of asthmatic patients. The correct and early diagnosis of $\mathrm{OA}$ is of great preventive and socio-economic importance. However, few studies exist on OA's prevalence in Catalonia and in Spain and those affected are mainly treated by the public health services and not by the occupational health services, which are private.
\end{abstract}

Objective: To determine the prevalence of OA in patients diagnosed with asthma in the Primary Healthcare system and to evaluate the socio-economic impact of OA in the Primary Healthcare system.

Methods/Design: We will carry out an observational, transversal and multi-center study in the Primary Healthcare Service in the Barcelona region (Catalonia, Spain), with 385 asthmatic workers aged between 16 and 64 who are currently working or have been working in the past. We will confirm the asthma diagnosis in each patient, and those meeting the inclusion criteria will be asked to answer a questionnaire that aims to link asthma to the patient's past employment history. The resulting diagnosis will be of either occupational asthma, work-aggravated asthma or common asthma. We will also collect socio-demographic information about the patients, about their smoking status, their exposure outside of the workplace, their work situation at the onset of the symptoms, their employment history, their symptoms of asthma, their present and past medical asthma treatment, and, in order to estimate the economic impact in the Primary Healthcare system, where they have been attended to and treated. Prevalence will link OA or work-aggravated asthma to the total of patients participating in the study with a asthma diagnosis.

Discussion: The results will show the prevalence of OA and work-aggravated asthma, and shall provide valuable information to set out and apply the necessary personal and technical measures, either in the public or in the occupational health services. No studies evaluating the costs generated by the OA in the Primary Healthcare system have been carried out.

Keywords: Epidemiology, occupational asthma, occupational health services, prevalence, primary health care.

\section{BACKGROUND}

Occupational asthma (OA) is a disease characterized by variable airflow obstruction and/or bronchial hyperactivity due to causes and conditions attributable to a particular occupational environment and not to any other factors out of

*Address correspondence to this author at the Primary Healthcare Centre Vallès Oriental, Catalan Health Institute, Carrer del Museu, 19, 08401 Granollers, Spain; Tel: 00349386005 22; Fax: 00349387060 04;

E-mail: vrs01b@gmail.com the workplace [1, 2]. Epidemiological and clinical evidence indicates that multiple agents inhaled at work can induce asthma (more than 300 according to current knowledge) [3, 4]. Table 1 shows the relationship between the principal agents inhaled and the workers with potential risk of developing occupational asthma.

\section{INTRODUCTION}

According to the pathogenic mechanism, we can distinguish three types of OA $[1,2,5,6]$ : 
1) Immunological OA. This appears after a latency period during which the individual does not yet respond to the causal agent. This may be either a substance of high molecular weight such as latex, enzymes, cereals and flours (typically, involving an IgE-mediated mechanism) or a substance of low molecular weight such as diisocyanates, metals, wood dusts or cleaning agents (in which case the existence of an IgE-mediated mechanism usually cannot be displayed).

2) Non-immunological OA. This is due to a toxic or irritating device. The best-studied form is the Reactive Airways Dysfunction Syndrome (RADS), due to high-dose exposure to an irritant agent that causes the onset of the symptoms within 24 hours. Chlorine, sulfur dioxide, ammonia and combustion products are the most common agents that can induce non-immunological OA.

3) Other forms of OA. This includes forms of OA with special and distinctive features such as asthma-like disorders or the asthma of aluminum producers.

Nonetheless, OA, is part of a wider concept, namely work-related asthma (WRA) [1, 3], which includes workaggravated asthma, characterized by a pre-existing or concurrent asthma disorder that is aggravated by work conditions and may be difficult to differentiate from actual occupational asthma.

$\mathrm{OA}$ is the most frequent respiratory occupational disease in industrialized countries [7]. The data on prevalence vary according to country, the specific population, the different designs of the epidemiological studies, and the definition of OA [2]. According to most studies [8], occupational asthma accounts for between $5 \%$ and $25 \%$ of asthmatic patients. A recent review study [9] estimated that the average attributable risk is $15 \%$. Considering that asthma affects, on average, $5-10 \%$ of the European adult population (about $5 \%$ in Spain) with a tendency to increase $[10,11]$, we are looking at a significant public health problem.

The correct and early diagnosis of OA is of great prognostic, preventive and socio-economic significance. Many different studies show that the sooner the medical treatment is established and the contact with the causative agent is avoided, the better the patient's prognosis is. However, the diagnosis of a new case of $\mathrm{OA}$ requires investigation on behalf of the employee's company with the aim to elucidate the causative agent and implement the necessary preventive and corrective measures (substitution of products, reduction of exposure, change of the workplace, use of collective and individual protection equipment, etc.) to improve the working conditions not only in the affected patient's workplace, but also in all similar places or for workers with similar exposures. This would prevent new cases (primary prevention).

To ensure proper primary prevention, cases must be correctly diagnosed. One of the main problems of occupational health in our country is that most occupational diseases are not diagnosed as such in the specialized occupational health services system (work-place accidents and occupational diseases insurance companies or the company prevention services). They are, in fact, diagnosed and treated at the Catalan Public Health Institute (Institut Català de la Salut, ICS) and, thus, are classified as common and not occupational diseases. Respiratory diseases and, specifically, OA are no exception. The MOR (Occupational Respiratory Diseases) [12] platform was created in Catalonia in 2002 to fill this gap; created by volunteer doctors (pneumologists, occupational medicine specialists, allergists and others) who collected a total of 174 cases of OA. During the same period, the official statistics on occupational diseases [13] only registered 42 cases of OA.

Many occupational asthmatics are treated in the Primary Healthcare system, either because they went there on their own initiative or because they were incorrectly referred from the occupational insurance companies. This fact has many negative consequences. Firstly, it is detrimental for the affected workers because even if they are following medical treatment, they continue to be exposed to the causative agent, and may become chronic patients and lose their capacity to work. Secondly, this is to the detriment of other workers performing similar tasks and with similar exposures as the employer does not take any preventive measures. Thirdly, this implies a clear dysfunction between the occupational healthcare system and the public health service, especially the Primary Healthcare system, due to the inappropriate and unjustified transfer of patients. The cost of treating and caring for these patients is borne, to a great extent, by the Primary Healthcare system.

The OA diagnosis consists of two phases. In the first phase, the asthma diagnosis has to be confirmed and in the second phase, asthma has to be associated with the work environment area and the occupational exposures.

1) Asthma diagnosis: The most relevant guidelines in our area, such as the British Guideline on the Management of Asthma [14] from the British Thoracic Society (BTS), the Global Strategy for Asthma Management and Prevention of the Global Initiative for Asthma [15] (GINA) and the Guía Española para el manejo del Asma [16] (GEMA) agree in stating that asthma symptoms, even if they are characteristic, are also non-specific and cannot constitute a diagnosis for the disease leading to the recommendation to perform an objective test that proves a reversible airflow obstruction. The GEMA proposes the application of a sequential algorithm in the Primary Healthcare system. This algorithm is based on clinical tests, pulmonary function and allergic sensitization.

2) Connection with the workplace (occupational asthma diagnosis): the establishment of the connection between asthma symptoms and occupational exposure may be established according to different levels of evidence, depending on the purpose and the circumstances. The OA individual clinical diagnosis requires the highest level of evidence and, in some cases, an absolutely confirmed diagnosis taking into account the medical, socio-economic and legal implications that it may imply. This leads to diagnosis algorithms that are very expensive, risky and not very affordable, with analysis such as the specific bronchial provocation testing that have to be performed in very specialized laboratories, which are 
Table 1. Relationship between the main inhaled agents and employees at potential risk of developing occupational asthma.

\begin{tabular}{|c|c|}
\hline Acrylate & Adhesive Manipulations \\
\hline Amines & Welding, varnish and lacquer operators \\
\hline Anhydrides & Users of plastics and epoxide resins \\
\hline Chloramine - $\mathrm{T}$ & Doorman, housekeeping \\
\hline Enzymes & Users of detergents, pharmaceutical workers, bakers \\
\hline Drugs & Pharmaceutical workers, health professionals \\
\hline Formaldehyde, glutaraldehyde & Hospital staff \\
\hline Seafood and Fish & Fish and seafood processors \\
\hline Metals & Welders, refiners \\
\hline Persulfate & Hairdressers \\
\hline Wood's powder & Forestry Workers, Carpenters, manufacturers specialized in carpentry. \\
\hline Solder & Electronic area workers \\
\hline Dyes & Textile workers \\
\hline
\end{tabular}

not available in the Primary Healthcare system. In both the health surveillance programs and in the epidemiological studies, the requirements are less strict and they aim to establish the link between the symptoms and the occupational exposure without the need to carry out very complex or expensive tests.

This study aims to estimate the prevalence of occupational asthma and asthma aggravated by working conditions among patients diagnosed with asthma as well as to discover the real impact on the Primary Health care system caused by under-diagnosis and inappropriate referral of OA.

This knowledge is necessary to take corrective action and achieve the ultimate goal: improving health and occupational prognosis of patients with OA and to improve risk prevention in companies avoiding the appearance of new cases.

\section{OBJECTIVES}

\section{Main Objective}

To determine the prevalence of occupational asthma in patients diagnosed with asthma in the Primary Healthcare system (public health service)

\section{Secondary Objectives}

1) To determine the prevalence of common asthma aggravated by the work environment.
2) To identify the distribution of occupational asthma according to the type of work activity carried out.

3) To determine the proportion of cases of occupational asthma accepted and controlled by the occupational health services (work-place accidents and occupantional insurance companies) out of the total of occupational asthma diagnoses.

4) Determine the welfare cost and the burden that the occupational asthma generates in the Primary Healthcare system.

\section{Methods/Design}

We will carry out an observational, transversal and multicenter study in the Primary Health Care Service in the Barcelona region (Catalonia, Spain), where there are 16 teams of Primary Healthcare which offer their services to very different types of areas (urban, semi-rural, etc.). A total population of 265,254 inhabitants, aged between 16 and 64, is assigned to these 16 teams.

\section{Study Subjects}

Fig. (1) shows the selection process of participants in the study. Asthmatics aged between 16 and 64 who are working or have ever worked and are assigned to the teams participating in this study.

The information source used to recruit the subjects of the study will be the electronic medical records (e-CAP) of the Primary Healthcare of the Institut Català de la Salut (ICS), due to the fact that all the participating centers belong to the 


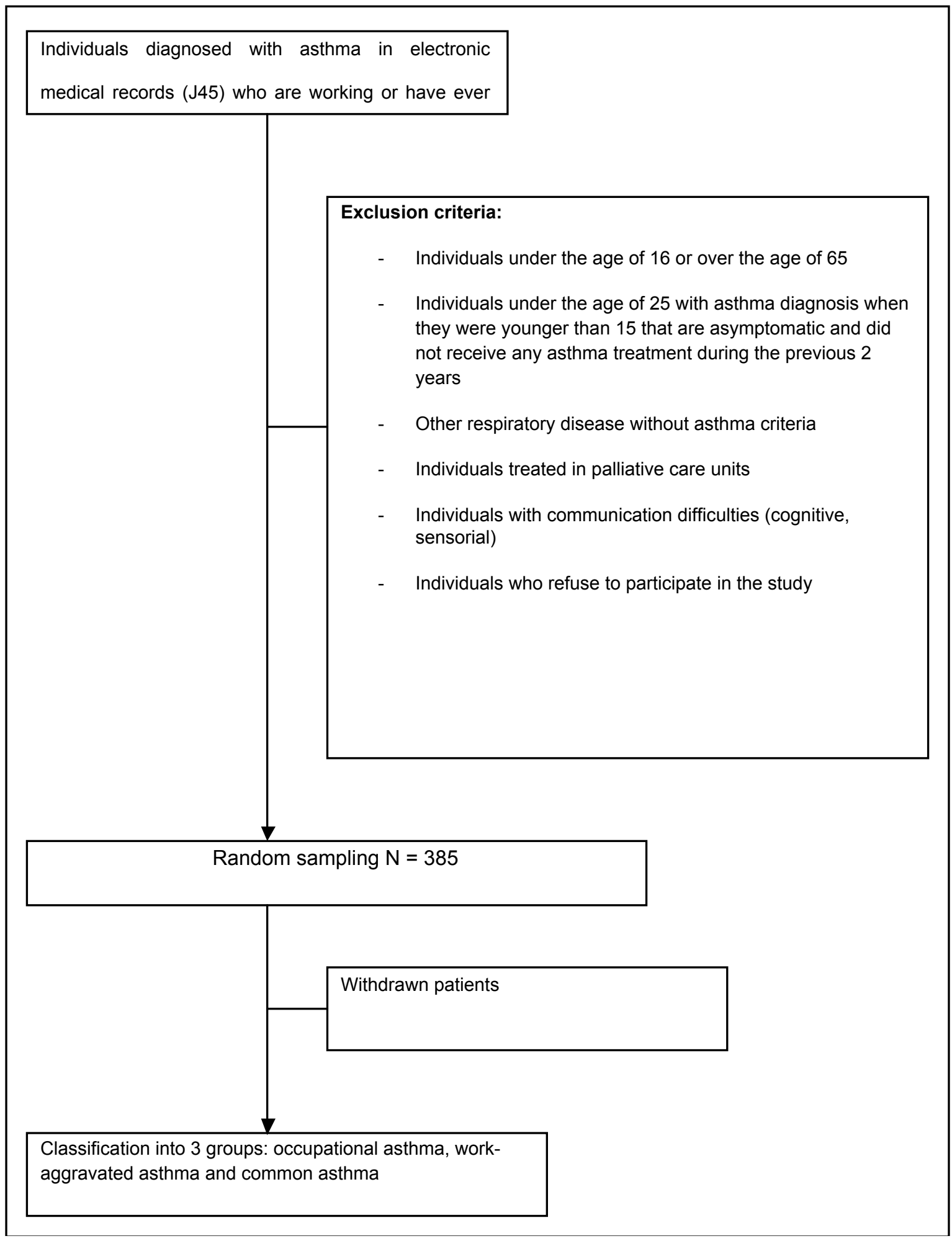

Fig. (1). Flow chart of sample selection.

public system and all of them have exclusively used the eCAP for the past 5 years.

\section{Inclusion Criteria}

i. Individuals diagnosed with asthma.

ii. Individuals aged between 16 and 64 . iii. Individuals who are working or have ever worked in the past.

iv. Individuals assigned to the teams participating in the study. 


\section{Exclusion Criteria}

i. Individuals under the age of 16 or over the age of 65 , since the study is focusing on the active working population.

ii. Individuals under the age of 25 with asthma diagnosis when they were younger than 15 that are asymptomatic and who did not receive any asthma treatment during the previous 2 years. These patients may have had childhood asthma that has already faded.

iii. Individuals having a respiratory disease but not meeting the criteria of asthma diagnosis.

iv. Individuals treated in the palliative care service.

v. Individuals included in the home care program.

vi. Individuals with communication difficulties (cognitive, sensory, language).

vii. Individuals who refuse to participate in the study.

viii. Individuals impossible to contact.

\section{Sample Size and Selection Method}

A sample size of 385 asthmatic patients will suffice to estimate with a $95 \%$ confidence and a precision $+/-3 \%$, a $10 \%$ of patients with occupational asthma among asthmatic patients. The selection of asthmatic subjects will be made using a simple random sampling based on the clinical computerized history (e-CAP) of the Primary Healthcare service of ICS.

\section{Study Variables}

By using a data collection notebook (DCN), which has been exclusively designed for the study, we will collect the following independent variables:

- Administrative variables: the date when the data are collected and the patient's ID code.

Socio-demographic variables: date of birth, gender (male, female) and country of origin.

- Variables associated with smoking habits: smoking habit (smoker, ex-smoker, has never smoked) and number of packs per year (in the case of smokers and ex-smokers).

- Variables associated with the exposure to nonoccupational triggers: pharmacologic treatments, pets and seasonal symptoms.

- Variables associated with working life: Current work situation of an active employee (including type of contract: self-employed or employment contract), unemployed, retired or permanent disability (in this case, we will state whether the disability was caused by asthma or specify any other reasons for the disability). Other information will include the name of the company where the patient is currently working, the year he/she started working there, the company's activity, the work carried out by the patient, the exposure to any substances (specify which ones), any job changes due to respiratory problems and whether work colleagues have similar symptoms (if so, specify how many people).
- Variables associated with the work situation when the asthma symptoms started: year of onset of asthma symptoms, asthma symptoms began before starting to work (yes/no), the name of the company where the patient was working at the onset of the symptoms, company's activity, work in the company, exposure to any substances (specify which ones), and the period of time from the moment of starting the work to the onset of the respiratory symptoms.

- Variables associated with the work history: work in other companies prior to the present, change of work due to respiratory problems, company's name and activity, work carried out in the company, exposure to any substances (specify which ones) and any accidental exposure to toxic substances that would have caused respiratory problems (specify which substance).

- Variables associated with the asthma symptoms: improved condition during the holidays period, improvement when they are not working, improvement during weekends and days off, worsening when at work, treatment for asthmatic problems in the occupational health service, changes of residence when the symptoms started, presence of pets at home for the first time when the symptoms started, changes in their usual medication that could have worsen the asthma (specify which drugs).

- Variables associated with current treatment: inhaled corticosteroids (specify type and dose), short and long-term bronchodilators (specify type and dose), antileukotrienes (specify type and dose) and possible dose increase when the patient works (specify the drug).

- Variables associated with the economic impact on the Primary Healthcare system: number of visits to the primary healthcare service due to asthma, cost of medical consultation, nursing consultation cost, number and cost of complementary tests, number of procedures for temporal incapacity, duration (months) of disability, number of drugs consumed associated with the asthma treatment and the cost of asthma treatment. The history of healthcare services is totally drawn from the e-CAP for the year 2009. The rest of information is collected from the accurate data collection notebook from the patients. Cost calculations are referred to a single year, 2009.

The dependent variable will be the asthma diagnosis of each patient that will classify the subjects into 3 groups: occupational asthma, work-aggravated asthma and common asthma. The classification criteria according to the criteria for defining OA proposed by the American College of Chest Physicians [17] and the Sentinel Event Notification System for Occupational Risks (SENSOR) [1] will be as follows:

Occupational asthma: The symptoms begin in adulthood after commencing work, with temporal association between asthma symptoms and work, and exposure to some agents or processes known to be responsible for occupational asthma.

Work-aggravated asthma: Pre-existing asthma. The symptoms increase or require an increase in medication when the patient occupies a new position where he/she is exposed to harmful agents for the respiratory system or suffers new harmful exposures in the workplace.

Common asthma: when it is not possible to establish a relationship between asthma and the work environment. 


\section{Data Collection}

\section{Phase I (Study Preparation)}

There will be a meeting between the research team and the manager of each primary care team to explain the objectives and work methodology. The manager should present this to his/her team and encourage them to attend the meeting that will take place about 15 days later. All the doctors at each participating centre and one member of the research team will attend the second meeting. In fact, each one of the research team members will take care of one or more Primary Health teams and they will be the support researcher for these professionals during the entire study. Within one week, the interested doctors will contact the corresponding person in the research team to confirm participation.

Subsequently, there will be a day designated to train the participants on asthma diagnosis, the differential diagnosis of Chronic Obstructive Pulmonary Disease and the occupational asthma specific features. This training will be given by one of the members of the research team and all the doctors participating in the study will be obliged to attend. We will take this occasion to explain in detail the data collection notebook (DCN) for the study and its use. There will be a pilot test with $15-20$ patients, who will not be included in the study to avoid affecting the final results. We will evaluate the inclusion process, the data collection and the established circuits with them.

\section{Phase II (Sample Selection)}

The sample will be obtained through the electronic medical records list of the patients assigned to each one of the practitioners participating in the study. The participating practitioners will receive a computerized list of the patients registered with asthma diagnosis.

According to the considerations explained in the section on subjects of study, each practitioner participating will analyze the clinical history of their patients included in the study and will evaluate the following information:

- In those cases diagnosed of asthma, he/she will have to confirm if they meet the criteria of asthma diagnoses of this study.

- In the cases that the clinical history is not clear enough, the patients will be called to perform a new anamnesis and additional tests if necessary.

This first selection will allow us to make a list with the asthma patients of each participant practitioner and if any patient presents a doubtful diagnosis, they will be evaluated by a member of the research team. Every doctor will know the number of patients that they will have to recruit for the study, so once the number required has been reached, the collaboration will be considered complete.

\section{Phase III (Study Development)}

- Inclusion of participants: The participating doctor will phone each patient to arrange an appointment or will use any consultation that the patient makes in the centre to evaluate if he/she presents any exclusion criteria and if he/she is an appropriate candidate to participate in the study. He will ask for the patient's authorization to be included in the study and sign the informed consent form. If the patient does not wish to sign, he/she will be excluded from the study and the reason why he does not wish to participate will be recorded. A seven-digit identification number will be used to ensure that the patient remains anonymous. At this point, the participating doctor's work will finish. The rest of the study will be carried out by the research team.

- Data collection: If the patient agrees to participate in the study, he/she will have to go to his/her centre for data collection. Annex 1 shows the Case Report Form for the study. During the interview he/she will be asked whether he/she is working or has ever worked. If the answer is affirmative, he/she will be given a questionnaire on occupational asthma, where we perform an exhaustive review of all the different work phases of the subject to try to avoid an eventual bias of memory. We will have a list with the different occupations and activities that are related with $\mathrm{OA}$ and, for each activity, the main chemical agents and/or products causing OA.

This questionnaire will be applied by one person who will be specifically hired for the sole purpose of performing this task in all the centers. Once implemented, the questionnaire will be encoded by a single member of the research team specialized in occupational asthma, with the aim of avoiding subjective variability in the interpretation of the information. The information will be entered into a database by the person giving out the questionnaire, who does not belong to the research team.

- Asthmatics classification: A member of the research team, expert in occupational asthma will carry out the data evaluation with the purpose of establishing one of the following diagnoses: occupational asthma, work-aggravated asthma and common asthma. This will be performed through the classification criteria defined in the previous section of study's variables. In case of doubt, the research team will discuss each case to improve the bases for classification.

\section{Phase IV (Final Evaluation and Results Dissemination)}

In the final evaluation, we will carry out the statistical analysis of the data obtained and will prepare the final report and publish the results in international journals and present them at international and national meetings.

\section{Analytic Plan}

The quality control of the data will be carried out by looking for unusual or illogical values, registry errors and inconsistent answers. We will make univariate descriptive statistics of all the variables collected. For each one of them, we will calculate the frequency and the percentage if they are discrete variables and the mean average and the standard deviation or median and the interquartile range if they are continuous variables.

In order to provide an answer to the main objective, the prevalence of occupational asthma will be calculated as the number of patients with the variable result equal to the occupational asthma diagnosis, divided by the total number of patients participating in the study who have received a final evaluation of asthma. 
We will also calculate the prevalence of work-aggravated asthma, but in this case the numerator will be the number of patients with the variable result equal to the work-aggravated asthma (first secondary objective).

In order to provide an answer to the second secondary objective, descriptive bivariate statistics will be calculated to study the possible links between the prevalence of occupational asthma and the different independent variables related to work activity (variables related to the working life, the work situation when the asthma symptoms began and the work history) by Chi-square test or Fisher exact test for comparison of proportions when the independent variable is qualitative, and by Student's test or analysis of the variance (ANOVA) for the comparison of means when the independent variable is continuous and normally distributed and non-parametric tests (Mann-Whitney U test or KruskalWallis test) for the comparison of medians when the independent variable is continuous non-normally distributed.. Continuing with the second secondary objective, we will carry out a multivariate analysis using a polytomous logistic regression, where the dependent variable will be the asthma diagnosis (common asthma / occupational asthma / work-aggravated asthma). In this multivariate model we will adjust by the different independent variables deemed to be of interest in the bivariate analysis $(p<0.10$ or clinically relevant), as age, sex and country of origin as demographic variables; smoking habit, age of onset of asthma symptoms, among other variables as healthcare variables, and current work situation, type of profession to the onset of symptoms of asthma, among other variables as occupational variables. No variable that have been used to identify OA and WEA cases will be included.

We will also calculate the number of patients with occupational asthma dealt with by work insurance companies. By dividing this by the total number of patients with occupational asthma, we will answer the third secondary objective.

The analysis of additional healthcare costs and the cost that occupational asthma generates in the Primary Healthcare will be measured by the variables related to the economic impact into the Primary Healthcare in the study (fourth secondary objective). All statistical tests will be two-tailed with a confidence level of $95 \%$. The Stata 13 statistical package will be used.

\section{Study Limitations}

Given the procedure used to recruit the subjects, we may receive doubtful or incorrect asthma diagnoses. To avoid this problem, we will review the diagnostic criteria for all the subjects of the sample who are classified as asthmatic in the e-CAP. If this diagnosis is not confirmed, the subject will be excluded from the sample and if we have any doubts, the medical history will be reviewed and all complementary tests will be carried out if necessary. If the participating doctor still has doubts, he/she will consult the research team before including the patient in the study.

A questionnaire on occupational asthma shall be used, including an exhaustive review of all of the different work phases of the subject in an attempt to avoid potential memory bias. We shall provide a list of the different occupations and activities that are related to occupational asthma along with the main chemical agents and/or products causing occupational asthma for each activity (see annex 1).

\section{DISCUSSION}

Considering that the aim of the study is to identify a group (patients with OA) to evaluate the magnitude of the problem in the Primary Healthcare system, the specific confirmation of individual cases is not as essential as the global vision of the problem. This is why, following the criteria of organizations and expert groups (American College of Chest Physicians, ACCP; Sentinel Event Notification System for Occupational Risk, SENSOR) $[1,17]$, we have established the link between the clinical chronology and work environment as a basis for the diagnosis of $\mathrm{OA}$ in the design plan for the study, considering the clinical and occupational history of the patient at all times [18].

From an ethical point of view, the study will identify the OA patients who were classified as having common asthma and will allow refer them to the appropriate service (occupational health services or other labor-related insurance companies) with the benefits that this may bring to the patient from a preventive, prognostic, legal and an economic point of view (recognition of an occupational disease).

A very important bias in the asthma diagnosis is the clinical similarity to chronic obstructive pulmonary disease (COPD). On the one hand, there are patients diagnosed with COPD who are, in fact, asthmatic. There are also cases of patients who are smokers where COPD and asthma co-exist. According to the GEMA guideline and the differential diagnosis table included within, the present study will include, in the first stage of the screening, COPD diagnosed patients. But patients with COPD are not included in the sample; we review the clinical cases in which this diagnose is not clear whether it was COPD or asthma, and once confirmed that was not COPD, the case was included in the sample.

The results obtained can have a prominent epidemiological and welfare impact. From an epidemiological perspective, occupational asthma ethiology is not usually evaluated, neither is the deterioration that the work environment can cause to asthmatic patients. From a medical-care point of view, this can imply a poor level of control of the disease, a higher economic cost and a very significant medical burden.

We consider that despite the evidence that many occupational agents can induce asthma or significantly aggravate preexisting asthma, this issue is not usually investigated in the day to day practice [19], and therefore we do not have any objective data to quantify this fact.

Given the fact that the geographical environment of this study is very diverse (from rural areas to highly industrialized regions), we believe that this is a good territorial model to extract prevalence data that can be generalized. On the other hand, considering that in Catalonia the health system is homogeneous, results on the OA cost will be extrapolated. Thanks to the employment questionnaire, the workplaces presenting the highest risk of developing asthma or that make pre-existing asthma become 
worse and out of control are expected to be detected. We will also have more objective data that will allow us to advise the patients about the risk of certain work environments and the preventive measures to take.

In Catalonia, this is an issue of particular interest, taking into account the lines set out in the current Health Plan, which considers as key issues both the improvement in the detection and the declaration of occupational diseases treated in the Primary Healthcare section of the public health system and the establishment of recommendations for prevention and control.

Occupational health services are quite heterogeneous depending on country. However, primary health care or general medicine tends to be at the heart of the initial suspicion of work-related asthma. For example, when establishing the asthma diagnosis in adult patients, primary health care physicians should always consider the potential work-related origin of the illness and should carry out the proper anamnesis of their labor background [20]. Therefore, we feel that the results of this study may be of interest, given that they reinforce the idea that many asthma cases are diagnosed and treated in primary health care consultations and that not all are derived from the occupational health care centers. We believe that this is not a situation that is unique to Catalonia but rather, that it is common across the Spanish National Health System and, by extension, to all countries that organize their healthcare services based on regulatory (gatekeeper) access to a universal healthcare system for the general population. On the other hand, we also feel that it may be extended to those systems in which the healthcare and the occupational healthcare networks are not fully integrated.

The project results will be easily applied and may be extended to all the Primary Healthcare services. Furthermore, in the event of achieving the objectives of the study, we expect to rationalize or reduce costs and improve in efficiency.

We believe that the study design is of interest from an epidemiological point of view since we propose the study of the health problem on a population basis $(265,000$ inhabitants in a defined area). This design also allows us to determine the diagnostic appropriateness of asthma as all of the diagnoses shall be reviewed by medical experts. Furthermore, there are very few studies on the prevalence of work-related asthma that offer a breakdown of the impact of assistance on primary healthcare services. We also feel that the diffusion and publication of the research protocol facilitates its evaluation, allowing the study to be included in future systematic reviews [21] and offering transparency to the research process as it offers a clear description of the procedures followed, making its reproduction possible in other situations

\section{ETHICAL CONSIDERATIONS}

The project will be presented to the patient during his/her first appointment with the Primary Healthcare professional. The doctor will distribute an information sheet about the study and an informed consent form and will ask for the patient's permission for his/her voluntary participation.
The informed consent form will contain the terms of the general and particular ethical conditions regarding his/her privacy, anonymity, confidentiality rights (therefore, only the researchers and monitors/auditors will have access to the data of the participating subjects), cancellation and information rights.

The researchers agree to comply with the current rules of Good Clinical Practice and the applicable requirements of the Declaration of Helsinki. For this reason, we will use a 7digit code for the identification of each patient: the two first digits will identify the centre, the two following ones the professional responsible for the evaluation, and the last three digits will correspond to the patient, in order of entry into the study. The benefits for the patients participating in this study are the following: the possibility of establishing a correct diagnosis of their asthma disease and its association with their work environment. We will explain the subjects that this study is completely confidential and that their employment company will not be informed about this without his/her explicit consent.

This study was approved by the Ethics Committee of Clinical Research in Primary Care Research Institute Jordi Gol (Barcelona, Spain).

\section{AUTHOR'S CONTRIBUTIONS}

VRS, JSM, EHH, RVR, RPV contributed to the original idea of the project on the prevalence of occupational asthma in patients diagnosed of asthma in the Primary Healthcare system. VRS, JSM, EHH, RVR, RPV, XBP and GPL participated in the study design. LM has participated in the statistical analysis of data. PT and LM contributed to formulating the research question, conception and study design and they also participated in the elaboration research protocol and drafting of the manuscript of this paper. VRS, JSM, EHH, RVR, RPV and XBP helped in coordinating the study. All authors critically read and approved the final manuscript.

\section{ABBREVIATIONS}

$$
\begin{array}{ll}
\text { ACCP } & \text { American College of Chest Physicians } \\
\text { ANOVA }= & \text { Analysis of Variance } \\
\text { BTS } & \text { British Thoracic Society } \\
\text { COPD }= & \text { Chronic Obstructive Pulmonary Disease } \\
\text { e-CAP }= & \text { Electronic Medical Records in Catalan Primary } \\
& \text { Care Providers } \\
\text { GEMA }= & \text { Spanish Guide on the Management of Asthma } \\
\text { GINA }= & \text { Global Initiative for Asthma } \\
\text { GRRVO } & \text { Respiratory Research Group of Vallès Oriental } \\
\text { ICS }= & \text { Catalan Institute of Health (Institut Català de la } \\
\text { MOR }= & \text { Occupational Respiratory Diseases } \\
\text { NDC }= & \text { Notebook Data Collection } \\
\text { OA }= & \text { Occupational Asthma } \\
\text { RADS }= & \text { Reactive Airways Dysfunction Syndrome }
\end{array}
$$


SAP $=$ Service Primary Care

SENSOR $=$ Sentinel Event Notification System for Occupational Risk

WRA = Work-Related-Asthma

\section{CONFLICT OF INTEREST}

The authors confirm that this article content has no conflict of interest.

\section{ACKNOWLEDGEMENTS}

We would like to acknowledge the invaluable collaboration of Dr. Joan Pujol, of Pati Luque and of Dr. Laia Jaquet, who have provided us with their contributions and their perseverance in developing this protocol.

This project has received a grant from the Primary Care Research Institute Jordi Gol (Barcelona, Spain) in the form of support for research in primary healthcare 2008.

Anna Abad Carrilla contributed to the original idea, who died prior to the commencement of the study.

\section{GRRVO ASSOCIATED RESEARCHERS}

Acosta Ginesa, Aguyé Amada, Albi Anna, Antoja Pere, Anton Gloria, Ardite Melani, Ariasol Merce, Armenteros M.José, Arumi Montse, Bilardi Alejandro-José, Blanché Xavier, Calvo Maria, Carrion Eduard, Casermeiro Jose, Castellet Montse, Castillo Leonor, Cerrillo Carmen, Cobos Lola, Espinasa Josep, Estafanell Anna, Forés Didac, Freire Mercedes, Galvez Susana, Garcia Angel, Garcia Irene, Gil Montse, Gonzalez Judith, Grau Isabel, Hernández Enric, Hernandez Eustaqui, Hernandez Felipe-Modest, Herrero Milagros, Herrero Valentina, Iglesias Genis, Jorba Èlia, Jou Neus, Lorenzo Margarita, Malfeito Regina, Martí Jordi, Martínez Rafael, Martinez Xavi, Masuet Sandra, Miramanda David, Mogas Joan, Molina Sabina, Monso Carles, Montes Laura, Moragues Carolina, Muñoz Laura, Navarro Elisabeth, Olivares Ignacio, Ortega Julian, Ortega Ramón, Parera Anna, Pastor Marta, Pereira Carmen, Pérez Ana $\mathrm{M}^{\mathrm{a}}$, Pérez AnaPatricia, Perez Anna, Perez Santiago, Prat Mireia, Presas Miquel, Ralla Jordi, Ramiro M ${ }^{\mathrm{a}}$ Luz, Rodellar M.Teresa, Roig Lidia, Romanyà Fina, Rosàs Mireia, Ruiz Escolàstica, Sanchez Consol, Serracant Alejandro, Sivecas Joan, Torras Isabel, Turnes Ana, Utges Agustí, Velasco Rafael, Velayos Ramon, Viaplana Josep, Vila Rosa, Vilageliu Marga, Zamorano Enric.

\section{APPENDIX}

ANNEX 1: Data Collection Logbook (DCL) for the study OCCUPATIONAL ASTHMA, IMPACT IN PRIMARY CARE

INSTRUCTIONS: Correctly fill in all of the data in CAPITAL LETTERS. For questions with different answer options, mark the correct box with an X.

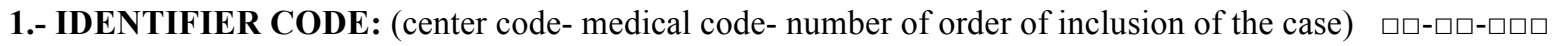

IN THE CASE IN WHICH THE INTERVIEW MAY NOT BE CONDUCTED AND THE PATIENT IS EXCLUDED,
MARK THE REASON FOR THIS:
$\square$ CANNOT BE LOCATED
$\square$ REFUSES TO PARTICIPATE
$\square$ CHANGE OF ADDRESS
$\square$ DEATH
$\quad \square$ DID NOT APPEAR
$\square$ OTHER, SPECIFY:

\section{2.- INTERVIEW DATE: $\square \square-\square \square-\square \square \square$}

3.- DATE OF BIRTH: $\square \square-\square \square-\square \square \square$

\section{4.- PLACE OF BIRTH:}

PROVINCE:

COUNTRY:

5.- GENDER: $\square$ MALE $\square$ FEMALE

6.- SMOKING HABIT:

$\square$ HAS NEVER BEEN A SMOKER

$\square$ SMOKER $\quad \rightarrow \quad$ PACKS/YEAR:

$\square$ EX-SMOKER $\rightarrow$ PACKS/YEAR: 
(APPENDIX) contd.....

7.- WORK SITUATION:

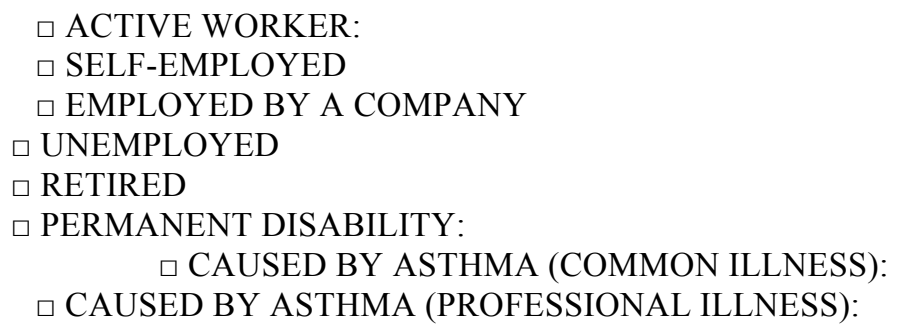

8.- YEAR OF ONSET OF ASTHMA SYMPTOMS:

(In case of uncertainty, introduce an approximate year)

9.- HAVE YOU BEEN DIAGNOSED WITH ALLERGIC RHINITIS?
$\square \mathrm{NO}$
$\square$ YES $\rightarrow \quad$ HOW MANY YEARS AGO?

10.- DO YOU HAVE ANY ALLERGIES?

$\square$ NO

$\square \mathrm{YES} \quad \rightarrow \quad$ TO WHAT?

11.- ARE ANY OF YOUR CLOSE RELATIVES ASTHMATICS?

$\square \mathrm{NO}$

$\square$ YES, SPECIFY:

12.- HAVE YOUR ASTHMA SYMPTOMS WORSENED SINCE YOU BEGAN TAKING ANY OF THESE DRUGS?
BETA-BLOCKERS: $\square \mathrm{NO} \quad \square$ Yes

ASPIRIN-NSAIDS: $\square$ NO $\square$ Yes

I HAVE NEVER TAKEN ANY OF THESE DRUGS: $\square$

OTHERS: $\quad \square$ NO $\square$ YES, SPECIFY:

13.- DO YOUR ASTHMA SYMPTOMS WORSEN WHEN YOU ARE IN CONTACT WITH ANY DOMESTIC ANIMALS?
$\square \mathrm{NO}$
$\square$ YES, SPECIFY:

14.- DO YOUR ASTHMA SYMPTOMS WORSEN DURING ANY SEASONS OF THE YEAR?
$\square \mathrm{NO}$
$\square$ YES, SPECIFY:

15.- DO YOUR ASTHMA SYMPTOMS WORSEN OR IMPROVE IN ANY SPECIFIC LOCATIONS?
$\square \mathrm{NO}$
$\square$ IMPROVE, SPECIFY:
$\square$ WORSEN, SPECIFY:

16.- IF YOU HAVE CHANGED RESIDENCY, HAVE YOUR ASTHMA SYMPTOMS WORSENED OR IMPROVED?
$\square \mathrm{NO}$
$\square$ HAVE IMPROVED, SPECIFY:
$\square$ HAVE WORSENED, SPECIFY:

17.- SINCE YOUR ASTHMA SYMPTOMS BEGAN, HAVE YOU BEEN COMPLETELY ASYMPTOMATIC FOR ANY EXTENDED PERIOD OF TIME (YEARS)?

$\square$ NO (If you mark this option go on to question 19)

$\square$ YES $\rightarrow$ PERIOD:

18.- DID THE SYMPTOMS START UP AGAIN ONCE YOU BEGAN WORKING?

$\square$ NO (If you mark this option go on to question 30)

$\square$ YES (If you mark this option go on to question 20)

19.- DID THE SYMPTOMS BEGIN BEFORE YOU BEGAN TO WORK?

$\square$ NO (If you mark this option go on to question 30)

$\square$ YES

20.- TIME SINCE STARTING TO WORK AND THE APPEARANCE OF RESPIRATORY SYMPTOMS: MONTHS:

21.- NAME OF THE COMPANY WHERE YOU WORKED WHEN THE SYMPTOMS BEGAN: 
22.- YEAR BEGINNING TO WORK WITH THIS COMPANY:

23.- COMPANY ACTIVITY:

CODE: $\ldots \ldots \ldots$ (to be filled out by the evaluator)

24.- WORK CARRIED OUT IN THE COMPANY WHEN SYMPTOMS BEGAN:

CODE: $\ldots \ldots \ldots$ (to be filled out by the evaluator)

25.- WERE YOU EXPOSED TO SUBSTANCES WHEN THE SYMPTOMS BEGAN?

$\square \mathrm{NO}$

$\square$ YES $\rightarrow \quad$ WHICH ONES?

$\square$ DON'T KNOW

26.- WHEN YOUR ASTHMA SYMPTOMS BEGAN, DID THEY IMPROVE UNDER THE FOLLOWING CONDITIONS?

ON VACATION: $\quad \square$ NO $\quad \square$ YES

ON LEAVE: $\quad \square$ NO $\quad \square$ YES

WEEKENDS: $\quad \square$ NO $\square$ YES

HOLIDAYS: $\quad \square$ NO $\square$ YES

27.- DID THE ASTHMA SYMPTOMS WORSEN WHEN YOU WERE AT WORK?

$\square$ NO

$\square \mathrm{YES}$

28.- DID OTHER CO-WORKERS HAVE SIMILAR SYMPTOMS?

$\square$ NO

$\square \mathrm{YES} \rightarrow$ HOW MANY CO-WORKERS?

$\square$ DON'T KNOW

29.- DO YOU CONTINUE WORKING IN THE SAME COMPANY?

$\square \mathrm{NO}$

$\square$ YES (If you mark yes go on to question 38)

30.- NAME OF THE CURRENT OR LAST COMPANY (last company in the case of retired, permanently

incapacitated or unemployed workers):

31- YEAR YOU BEGAN WORKING FOR THIS COMPANY:

32.- COMPANY ACTIVITY:

CODE: _ _ _ _ (to be filled out by the evaluator)

33.- YOUR WORK IN THE COMPANY:

CODE: $\ldots \ldots$ (to be filled out by the evaluator)

34.- ARE/WERE YOU EXPOSED TO SUBSTANCES?

$\square \mathrm{NO}$

$\square \mathrm{YES} \quad \rightarrow \quad$ WHICH ONES?

35.- DO/DID YOUR ASTHMA SYMPTOMS IMPROVE UNDER THE FOLLOWING CONDITIONS?

ON VACATION: $\quad \square$ NO $\square$ YES

ON LEAVE: $\quad \square$ NO $\square$ YES

WEEKENDS: $\quad \square$ NO $\square$ YES

HOLIDAYS: $\quad \square$ NO $\square$ YES

36.- DO/DID YOUR ASTHMA SYMPTOMS WORSEN WHEN YOU ARE AT WORK?

$\square$ NO

$\square$ YES

37.- DO/DID OTHER WORKERS HAVE SIMILAR SYMPTOMS?

$\square$ NO

$\square$ YES $\rightarrow$ HOW MANY CO-WORKERS?

$\square$ DON'T KNOW

38.- IN YOUR CURRENT COMPANY, HAVE YOU CHANGED JOBS DUE TO RESPIRATORY PROBLEMS?

$\square$ NO (If you mark this option, go on to question 44)

$\square$ YES

39.- JOB ACTIVITY CARRIED OUT:

CODE: (to be filled in by the evaluator) 
(APPENDIX) contd.....

40.- ARE YOU EXPOSED TO SUBSTANCES?

$\square$ NO

$\square$ YES $\rightarrow \quad$ WHICH ONES?

41.- DO YOUR ASTHMA SYMPTOMS WORSEN UNDER THE FOLLOWING CONDITIONS?

ON VACATION: $\quad \square$ NO $\square$ YES

ON LEAVE: $\quad \square$ NO $\square$ YES

WEEKENDS: $\square$ NO $\square$ YES

HOLIDAYS: $\quad \square$ NO $\square$ YES

42.- DO YOUR ASTHMA SYMPTOMS WORSEN WHEN YOU ARE AT WORK?

$\square \mathrm{NO}$

$\square$ YES

43.- DO OTHER CO-WORKERS HAVE SIMILAR SYMPTOMS?

$\square$ NO

$\square$ YES $\rightarrow$ HOW MANY COWORKERS?

$\square$ DON'T KNOW

44.- DURING YOUR WORK EXPERIENCE, HAVE YOU SUFFERED FROM ACCIDENTAL EXPOSURE TO TOXIC SUBSTANCES THAT HAS LED TO RESPIRATORY PROBLEMS?

$\square$ NO (If you select this option go to question 46)

$\square$ YES

45.- DO YOU KNOW WHAT THESE SUBSTANCES WERE?

$\square \mathrm{NO}$

$\square$ YES $\rightarrow$ WHAT WERE THEY?

46.- HAVE YOU EVER BEEN TREATED FOR ASTHMA BY YOUR MUTUAL INSURANCE COMPANY?

$\square$ NO (If you select this option go to question 48)

$\square$ YES

47.- THE ASTHMA FOLLOW-UP TREATMENT WAS CARRIED OUT BY:

$\square$ THE MUTUAL INSURANCE COMPANY

$\square$ THE CATALAN INSTITUTE OF HEALTH (ICS)

$\square$ OTHER, SPECIFY:

48.- HAVE YOU EVER BEEN ON LEAVE FROM WORK DUE TO ASTHMA?

$\square \mathrm{NO}$

$\square$ YES, WITH THE MUTUAL INSURANCE COMPANY

$\square$ YES, WITH THE ICS

49.- CURRENT TREATMENT FOR ASTHMA:

- Inhaled corticosteroids:

$\square$ Beclomethasone $\square$ Budesonide $\square$ Fluticasone Dosage/day:

- Bronchodilators:

- Short duration: $\square$ Salbutamol $\square$ Terbutaline Dosage/day:

$\square$ Only when needed $\quad \square$ Scheduled: $\quad$ Dosage/day:

- Extended duration: $\square$ Salmeterol $\square$ Formoterol Dosage/day:

- Anti-leukotrienes: $\quad \square$ Montelukast Dosage/day:

- Others, specify:

50.- SHOULD YOUR DOSAGE OF DRUGS BE INCREASED WHEN WORKING?

$\square \mathrm{NO}$

$\square$ YES $\rightarrow$ WHICH ONES?

51.- OTHER TREATMENTS:

52.- COMMENTS:

53.- DIAGNOSIS:

$\square$ OCCUPATIONAL ASTHMA

$\square$ COMMON ASTHMA

$\square$ COMMON ASTHMA EXACERBATED BY THE WORK ENVIRONMENT

\section{REFERENCES}

[1] Bernstein IL, Bernstein DI, Yeung MC, Malo JL. Definition and classification of asthma in the workplace. In: Bernstein IL, ChangYeung M, Malo JL, Bernstein DI, Eds. Asthma in the workplace. $3^{\text {rd }}$ ed. New York: Taylor and Francis 2006; pp. 1-8.

[2] Mapp CE, Boschetto P, Maestrelli P, Fabbri LM. Occupational asthma. Am J Respir Crit Care Med 2005; 172: 280-305.
[3] Chang-Yeung M, Malo JL. Aetiological agents in occupational asthma. Eur Respir J 1994; 7: 346-71.

[4] Mapp CE. Agents, old and new, causing occupational asthma. Occup Environ Med 2001; 58: 354-60.

[5] Vandenplas O, Malo JL. Definitions and types of work-related asthma: a nosological approach. Eur Respir J 2003; 21: 706-12. 
[6] Martínez RO, Abu Shams K, Alday Figueroa E, et al. Guidelines for occupational asthma. Arch Bronconeumol 2006; 42: 457-74.

[7] Kogevinas M, Antó JM, Sunyer J, Tobias A, Kromhout H, Burney P. Occupational asthma in Europe and other industrialised areas: a population-based study. Lancet 1999; 353: 1750-54.

[8] Mannino DM. How much asthma is occupationally related? Occup Med 2000; 15: 359-68.

[9] Balmes J, Becklake M, Blanc P, et al. American Thoracic Society Statement: Occupational contribution to the burden of airway disease. Am J Respir Crit Care Med 2003; 167: 787-97.

[10] Chinn S, Jarvis D, Burney P, et al. Increase in diagnosed asthma but not in symptoms in the European Community Respiratory Health Survey. Thorax 2004; 59: 646-51.

[11] Urrutia I, Aguirre U, Sunyer J, et al. Changes in the prevalence of asthma in the Spanish cohort of the European Community Respiratory Health Survey (ECRHS-II). Arch Bronconeumol 2007; 43: 425-30.

[12] Orriols R, Costa R, Albanell M, et al. Malaltia Ocupacional Respiratòria (MOR) Group: Reported occupational respiratory diseases in Catalonia. Occup Environ Med 2006; 63: 255-60.

[13] Generalitat de Catalunya. Departament de treball i indústria. Sinistralitat laboral a Catalunya any 2002. Col·lecció de prevenció de riscos laborals.
[14] British Thoracic Society; Scottish Intercollegiate Guidelines Network: British guideline on the management of asthma. Thorax 2003; 58(Suppl 1): i1-94.

[15] Global Initiative for Asthma (GINA): Global strategy for asthma management and prevention. Updated 2009 [http://www.ginasthma.com]

[16] Moral PV, Gutiérrez AFJ, Clarà CP, et al. Guia Española para el Manejo del Asma. Arch Bronconeumol 2003; 39(Supl 5): 3-42.

[17] Chang-Yeung M. Assessment of asthma in the workplace. Chest 1995; 108: 1084-117.

[18] Malo JL, Ghezzo M, L'Archevêque J, Lagier F, Perrin B, Cartier A. Is the clinical history a satisfactory means of diagnosing occupational asthma? Am Rev Respir Dis 1991; 143: 528-32.

[19] Rachiotis G, Savani R, Brant A, MacNeill SJ, Taylor NA, Cullinan P. Outcome of occupational asthma after cessation of exposure: a systematic review. Thorax 2007; 62(2): 147-52.

[20] Tarlo S, Lemiere C. Occupational asthma. N Engl J Med 2014: 370: 640-9.

[21] Torén K, Blanc PD. Asthma caused by occupational exposures is common- a systematic analysis of estimates of the populationattributable fraction. BMC Pulmonary Med 2009; 9: 7.

(C) Rabell-Santacana et al.; Licensee Bentham Open.

This is an open access article licensed under the terms of the Creative Commons Attribution Non-Commercial License (http://creativecommons.org/licenses/by-nc/4.0/) which permits unrestricted, non-commercial use, distribution and reproduction in any medium, provided the work is properly cited. 